\title{
Developments in the control of bacterial kidney disease of salmonid fishes
}

\author{
D. G. Elliott ${ }^{1}$, R. J. Pascho ${ }^{1}$, G. L. Bullock ${ }^{2}$ \\ ${ }^{1}$ National Fisheries Research Center-Seattle, Bldg. 204, Naval Station Puget Sound, Seattle, Washington 98115, USA \\ ${ }^{2}$ National Fish Health Research Laboratory-Leetown, Box 700, Kearneysville, West Virginia 25430, USA
}

\begin{abstract}
Bacterial kidney disease of salmonid fishes, caused by Renibacterium salmoninarum, was first reported more than $50 \mathrm{yr}$ ago; nevertheless, large gaps persist in our knowledge of the infection particularly in methods for its control. In the 1950's, principal control measures consisted of prophylactic or therapeutic feeding of sulfonamides, which were later supplanted by the antibiotic erythromycin Chemotherapy has effected some reduction of mortality, but benefits are typically transient and mortality usually resumes after the drug is withdrawn. Some studies have indicated that diet composition affects the prevalence and severity of the disease. Although tests of chemotherapeutants and diet modification have continued, research emphasis has shifted partly toward prevention of the disease by breaking the infection cycle. It is now generally accepted that $R$. salmoninarum can be transmitted both vertically and horizontally. Experimental evidence indicates that immersion of newly fertilized eggs in iodophor or erythromycin does not prevent vertical transmission. However, the injection of female salmon with erythromycin before they spawn shows promise as a practical means of interrupting vertical transmission. The results of attempts to prevent infection of juvenile salmonids by vaccination against bacterial kidney disease have been disappointing, thus underscoring a basic need for a better understanding of protective mechanisms in salmonids. The recent development of more sensitive and quantitative detection methods should aid in evaluating the efficacy of current and future control strategies.
\end{abstract}

\section{INTRODUCTION}

Bacterial kidney disease (BKD) of salmonid fishes, caused by the fastidious slow-growing Renibacterium salmoninarum, was first described from Scotland under the name Dee disease in 1930 (Smith 1964) and from the United States in 1935 (Belding \& Merrill 1935). Since these first reports, BKD has been isolated in virtually all parts of the world where wild or cultured salmonids occur (Fryer \& Sanders 1981, Klontz 1983). Serious mortality has been documented in juvenile salmonids in both fresh water and salt water, as well as in prespawning adults.

The disease can be transmitted directly by the feeding of raw viscera from infected fish (Wood \& Wallis 1955) or horizontally from infected fish sharing the same water supply (Mitchum \& Sherman 1981, Bell et al. 1984). It is the only bacterial disease of fishes that has conclusively been shown to be transmitted vertically (Bullock et al. 1978, Evelyn et al. 1986c). Although Renibacterium salmoninarum shows a predilection for kidney tissues, other organs are also infected; by the time clinical signs appear, the bacterium is usually systemic. A notable characteristic of infection is the apparent survival and multiplication of the bacterium inside phagocytic cells - macrophages, monocytes, and possibly polymorphonuclear leukocytes (Young \& Chapman 1978, Bruno 1986). This intracellular survival of the pathogen has often been cited as a major factor limiting the usefulness of many of the therapeutic measures that have been tested (Wolf \& Dunbar 1959, Bullock 1980, Klontz 1983, Austin 1985, Getchell et al. 1985, Sakai et al. 1986). In fact, BKD is considered by many to be among the most difficult of bacterial fish diseases to control. Despite many years of research, the pathogenesis and epizootiology remain poorly under- 
stood. Accordingly, the development of effective strategies for prevention and treatment has been hindered

Beginning in 1960, a control measure that effectively reduced $B K D$-associated mortality in juvenile hatchery-reared salmon was the pasteurization of salmon viscera and carcasses used in salmon feed (Fryer \& Sanders 1981). Furthermore, by the 1960 's, active testing of chemotherapeutic agents had resulted in the identification of several antimicrobial compounds that were potentially efficacious in increasing the survival of fish from infected populations. Research on chemotherapeutic agents has continued, but research has also been extended to other control measures such as diet modification, vaccination, and the interruption of horizontal and vertical transmission. Within the past $15 \mathrm{yr}$, the development of more sensitive and quantitative techniques for detecting Renibacterium salmoninarum infections has enhanced the ability of scientists to evaluate the effectiveness of potential control measures. We here summarize recent advances in methods for reducing the impact of $B K D$ in trout and salmon populations.

\section{CHEMOTHERAPY AND CHEMOPROPHYLAXIS}

Research on the control of BKD with chemotherapy and chemoprophylaxis began during the 1950's Rucker et al. (1951) reported that the incorporation of sulfadiazine into diets (264 $\mathrm{mg}$ per $\mathrm{kg}$ body weight for $7 \mathrm{~d}$, then $132 \mathrm{mg}$ per $\mathrm{kg}$ body weight for $21 \mathrm{~d}$ ) reduced $\mathrm{BKD}$ mortality in juvenile sockeye salmon Oncorhynchus nerka. Other researchers also reduced mortality by feeding certain sulfonamides (Earp et al. 1953, Rucker et al. 1954, Snieszko \& Griffin 1955, Wood \& Wallis 1955, Allison 1958); however, all noted a recurrence of mortality when sulfonamide therapy was stopped. Wolf \& Dunbar (1959) later reported that, of 34 antibacterial compounds tested against 16 isolates of Renibacterium salmoninarum, the broad spectrum macrolide antibiotic erythromycin was among the most effective for inhibiting growth of the bacterium in vitro it also was the best of 10 compounds used in feeding trials with $R$. salmoninarum infected brook trout Salvelinus fontinalis. A daily erythromycin dosage of 100 mg per $\mathrm{kg}$ body weight for $21 \mathrm{~d}$ provided the greatest reduction in mortality.

\section{Oral chemotherapy}

Erythromycin has been widely used experimentally for oral chemoprophylaxis and chemotherapy of BKD in many salmonid hatcheries in the United States (Gro- man \& Klontz 1983), although it is not yet registered for this use by the United States Food and Drug Administration. Research on the efficacy of erythromycin treatment for BKD control has also continued in other countries. In England, Austin (1985) corroborated the results of Wolf \& Dunbar (1959), but found a $10 \mathrm{~d}$ treatment to be nearly as effective as a $21 \mathrm{~d}$ treatment in experiments conducted with rainbow trout Salmo gairdneri. Moffitt \& Schreck (1988), who fed erythromycin thiocyanate to juvenile chinook salmon Oncorhynchus tshawytscha at daily rates of 0.05 and $0.1 \mathrm{~g}$ per $\mathrm{kg}$ body weight, determined that erythromycin levels exceeding the in vitro minimum inhibitory concentration for Renibacterium salmoninarum (Groman 1983) accumulated in the kidney, spleen, liver, plasma, and skeletal muscle within $3 \mathrm{~d}$. High tissue and plasma concentrations were maintained for the duration of the $21 \mathrm{~d}$ feeding period. On the last day of antibiotic administration, concentrations of erythromycin were 4 - to 10 -fold greater in tissues and 2-fold greater in plasma of fish fed at the higher dosage than in those fed at the lower dosage. After treatment was stopped, erythromycin concentrations in the plasma and muscle tissue declined below detectable levels within $10 \mathrm{~d}$. Putative therapeutic levels were maintained for at least $19 \mathrm{~d}$ (the last day of testing) in the kidney, liver, and spleen of fish fed at the higher dosage; and in the kidney and liver of fish fed at the lower one.

Oral chemotherapy with erythromycin does not eliminate Renibacterium salmoninarum infections from all treated fish (Wolf \& Dunbar 1959, Austin 1985). The bacterium apparently can survive and multiply within host cells such as macrophages and perhaps polymorphonuclear leukocytes (Young \& Chapman 1978, Bruno 1986), and several authors (Wolf \& Dunbar 1959 , Klotz 1983, Austin 1985, Getchell et al. 1985) have suggested that this intracellular existence may protect organisms from exposure to therapeutic agents. In humans, however, erythromycin appears to be actively concentrated intracellularly by macrophages and polymorphonuclear leukocytes, a process which could augment the drug's effectiveness (Brittain 1987). It is not known if a similar process occurs in fish phagocytes. Another possible explanation for the incomplete effectiveness of erythromycin treatment may relate to the palatability of erythromycin. Feed rejection - apparently due to taste - has been reported when the antibiotic is fed at the recommended therapeutic level of $100 \mathrm{mg}$ per $\mathrm{kg}$ body weight (Piper 1961, Warren 1963, Schreck \& Moffitt 1987): Schreck \& Moffitt (1987) suggested that the effectiveness of the erythromycin would then be reduced.

In addition to erythromycin, certain other antibacterial compounds have shown promise for oral chemotherapy of BKD. Austin (1985) tested 79 com- 
pounds used on gram-positive bacterial infections Compounds shown to be effective against Renibacterium salmoninarum in vitro were further screened during feeding trials in which rainbow trout were either: (1) challenged by intraperitoneal injection of $R$. salmoninarum and then fed medicated diets for 1 to $21 \mathrm{~d}$ from the time clinical disease first became apparent (chemotherapy tests), or (2) adiminstered medicated diets for $10 \mathrm{~d}$ and then similarly challenged with $R$. salmoninarum $24 \mathrm{~h}$ later (chemoprophylaxis tests). Austin found that, in addition to erythromycin, penicillin $G$ and the macrolides clindamycin, kitasamycin, and spiramycin effectively reduced mortality in early clinical cases of BKD. Cephradine, lincomycin, and rifampicin were effective for chemoprophylaxis of $\mathrm{BKD}$, but were ineffective for therapy.

\section{Immersion chemotherapy}

In addition to experiments on oral chemotherapy with antibacterial compounds, limited work (summarized by Groman \& Klontz 1983) has been done with immersion treatments. Putative therapeutic serum levels of erythromycin were attained in juvenile Pacific salmon when the antibiotic was administered by a 3 min hyperosmotic infiltration procedure similar to that of Amend \& Fender (1976), or when fish were immersed for $15 \mathrm{~min}$ in water containing both the antibiotic and a surfactant such as Aerosol-OT or polyxylene sorbitan (Tweens). Although Groman \& Klontz (1983) suggested that such procedures may be useful for controlling BKD, the efficacy of the procedures has not been tested.

\section{Injection chemotherapy}

Besides their use for the control of BKD in juvenile salmonids, antibacterial compounds have been used to reduce $\mathrm{BKD}$-associated prespawning mortality in adults. BKD has been particularly devastating to the spring race of chinook salmon, partly because these fish return to the hatchery holding ponds during late spring or early summer and remain there, under less than optimal conditions, until they spawn in the late summer or fall (Fryer \& Sanders 1981). DeCew (1972), who examined the effectiveness of injecting adult spring chinook salmon with antibiotics, recommended that fish infected with Renibacterium salmoninarum and Aeromonas salmonicida be given 3 subcutaneous injections, at 21 d intervals, with 15000 to 30000 international units penicillin $\mathrm{G}$ procaine, 19 to $38 \mathrm{mg}$ dihydrostreptomycin sulfate, and 4 to $8 \mathrm{mg}$ oxytetracycline hydrochloride per kilogram body weight. The injections resulted in increases of 24 to $160 \%$ in adult survival and 30 to $250 \%$ in egg production. Teratogenesis of the mandible and fin that developed in the progeny of antibiotic-injected adults was reduced by allowing a 32 d interval between the last injection and the first day of spawning.

More recently, Groman \& Klontz (1983) reported significant reductions in the prespawning mortality of chinook salmon at several hatcheries by subcutaneous injection of erythromycin phosphate. They recommended injecting erythromycin phosphate at the rate of $11 \mathrm{mg}$ per $\mathrm{kg}$ body weight, beginning when the adult salmon enter the trapping facility, and continuing at 21 to $30 \mathrm{~d}$ intervals during holding until $30 \mathrm{~d}$ before spawning. Erythromycin injections of adult salmonids have been used at many private, state, and federal salmonid culture facilities in the United States, Canada, Japan, and Europe (Groman \& Klontz 1983). Peterson (1982) reported that repeated erythromycin injections (11 $\mathrm{mg}$ per $\mathrm{kg}$ body weight) given at 30 to $35 \mathrm{~d}$ intervals for over 1 yr successfully controlled BKD in adult cutthroat trout Salmo clarki bouvieri; however, no uninjected control fish were included in the test. Sakai et al. (1986) found that a single intraperitoneal injection of masu salmon Onchorynchus masou with erythromycin at $10 \mathrm{mg}$ per $\mathrm{kg}$ body weight $20 \mathrm{~d}$ before spawning resulted in $0.5 \%$ mortality in the treated fish compared with $2.3 \%$ mortality in the uninjected control fish. The BKD prevalence detected by Gram stain was $0.3 \%$ (1 of 372) for the injected fish and $1.3 \%$ (6 of 480 ) for the uninjected fish examined at spawning. Erythromycin injection of adults caused no detectable damage to progeny monitored to the alevin stage.

\section{Potential problems of chemotherapy}

Widespread use of antibacterial compounds for control of BKD could result in the development of drugresistant strains of Renibacterium salmoninarum by natural selection. Bell et al. (1988) developed an erythromycin-resistant strain in vitro by initially exposing the cells to $0.1 \mu \mathrm{g} \mathrm{ml}^{-1}$ erythromycin, and then to increasingly higher concentrations - up to $500 \mu \mathrm{g} \mathrm{ml}^{-1}$. The degree of erythromycin resistance of the strain declined, however, after 7 or more passages on erythromycin-free medium. The virulence of the erythromycin-resistant strain to sockeye salmon also was found to be lower than that of the parent strain; the attenuation appeared to be attributable more to serial passage on the culture medium than to an effect of erythromycin. There have been no reports in the literature of resistant $R$. salmoninarum resulting from the use of the antibiotic in fish, although Austin \& Rodgers (1980) reported the existence of several isolates, from 
diverse geographical locations, that exhibited erythromycin resistance when tested in vitro.

There also is concern that the use of antibacterials for the control of BKD may mask the extent of the disease problem instead of eliminating it, particularly in populations of juvenile anadromous salmonids. Austin (1985) noted that the small numbers of asymptomatic infected fish remaining at the conclusion of chemotherapy tests with erythromycin and kitasamycin could conceivably serve as a reservoir of infection. Some evidence exists that anadromous salmonids infected with Renibacterium salmoninarum while in fresh water may die upon entry into salt water (Banner et al. 1986). It has been suggested that stress associated with the transition from fresh water to salt water accelerates the mortality (Fryer \& Sanders 1981, Banner et al. 1983).

\section{DIET MODIFICATION}

Modifications of cultural practices have been suggested for reducing mortality (Klontz 1983), and among these, the effect of diet composition has generated considerable interest. As early as the 1960 's, there was some evidence that feeding dry diets containing corn gluten increased the prevalence of BKD among Pacific salmon Oncorhynchus spp., whereas the substitution of cottonseed meal afforded some resistance (Wood 1979).

In a related study, Wedemeyer \& Ross (1973) investigated the role of diet on the susceptibility of coho salmon Oncorhynchus kisutch. Groups of juvenile coho salmon were fed a dry diet containing either corn gluten or cottonseed meal for 1 mo, and were then challenged by feeding them viscera from infected fish for a week. Each group continued to receive the appropriate diet during and after challenge. Small numbers of fish were removed at regular intervals to measure the prevalence of $\mathrm{BKD}$ relative to pituitary activation, carbohydrate metabolism, acid-base balance, hematopoietic activity, and renal function. As determined by Gram stain, the prevalence of BKD did not differ significantly between the 2 diet groups. Results of this study suggested that a greater degree of nonspecific stress occurred among the fish fed corn gluten, as evidenced by an increased depletion of ascorbate.

Bell et al. (1984) measured the resistance of sockeye salmon to an experimental challenge after the fish were fed ascorbate, zinc, and manganese at various levels. For $231 \mathrm{~d}$ before challenge, groups of fish received a control moist diet, or diets containing one of 3 levels of ascorbate in combination with either a low level of manganese alone or high levels of both manganese and zinc. Subgroups of fish from each diet group were then challenged by intraperitoneal injection with one of 3 concentrations of Renibacterium salmoninarum. At each challenge dose, the best survival time occurred when the fish were fed a diet containing low levels of zinc and manganese, and the lowest level of ascorbate. Increasing the level of ascorbate reduced the survival time. Certain diets therefore affected susceptibility/ resistance to $\mathrm{BKD}$; unfortunately, none of them affected susceptibility/resistance to the stage where mortalities due to the disease were prevented.

The complexity of the interaction among diet components was suggested earlier by the results of Paterson et al. (1981b) who found that the prevalence of BKD lesions was lower in Atlantic salmon Salmo salar fed a diet high in the trace elements iron, copper, manganese: cobalt, iodine and fluorine, or low in calcium, than in those fed a commercial diet. These findings were the basis of two 1 yr studies (Lall et al. 1985, Paterson et al. 1985 ) in which the relation of dietary minerals to the prevalence of BKD was examined in a naturally challenged population of Atlantic salmon. An experimental semi-purified diet was supplemented with one of the following elements or combinations: (1) low calcium, (2) high zinc and magnesium, (3) high zinc, magnesium, copper, iron, manganese, cobalt, iodine, and fluorine, (4) high copper, iron, manganese, and cobalt, and (5) high iodine and fluorine. Trials were carried out in a production facility where the disease occurred each spring. This annual presence of the disease was used to evaluate the efficacy of each diet modification. Post-yearling Atlantic salmon obtained from another hatchery for both trials were BKD-negative by the indirect fluorescent antibody test before they were introduced to the production facility. The prevalence of $\mathrm{BKD}$ in mortalities and live samples was determined by the observation of clinical signs and the detection of Renibacterium salmoninarum in kidney smears by the fluorescent antibody technique (FAT). Both trials demonstrated that fluorine and iodine as dietary supplements reduced the occurrence of $\mathrm{BKD}$, but also suggested that the uptake of these minerals in the digestive tract or at the cellular level was reduced by high levels of zinc and magnesium. These findings agreed with those of Woodall \& LaRoche (1964), who correlated increased levels of iodine with a reduced severity of BKD, and with the recent work of Bowser et al. (1988), who correlated increased levels of fluoride with reduced $\mathrm{BKD}$ mortality. However, in contrast to the earlier results of Paterson et al. (1981b), the 1985 reports indicated no reduction of $\mathrm{BKD}$ prevalence in groups fed a low-calcium diet.

Sakai et al. (1986) attempted. to control BKD mortality by modifying the diet of groups of 1 - and 2-yr-old infected masu salmon in a hatchery The commercial dry diet fed was supplemented for $40 \mathrm{~d}$ with the following vitamins: $A, D, E, B_{1}, B_{2}, B_{6}, C, K_{3}$, calcium pan 
tothenate, folic acid, and inositol. During the feeding trial, there were no differences in the rates of mortality between control fish and those fed the fortified diet. The authors postulated that the failure of the vitaminsupplemented diet to recuce mortality could have been due to the intracellular proliferation or accumulation of Renibacterium salmoninarum in neutrophils.

\section{VACCINATION}

The marginal success of many tested BKD treatments has focused efforts on developing preventive strategies. The potential of BKD vaccination was first suggested by the work of Evelyn (1971). He demonstrated that specific agglutinins were produced in juvenile sockeye salmon injected with heat-killed Renibacterium salmoninarum cells emulsified in Freund's complete adjuvant. He also reported a definite anamnestic response following a second injection; the agglutinating titers $90 \mathrm{~d}$ after the last injection exceeded those in the initial response. Although the results indicated that sockeye salmon could mount an immune response to $R$. salmoninarum, the ability of the vaccinated fish to resist BKD was not tested.

Similar results were obtained by Paterson et al. (1981a) and Paterson et al. (1985) during a study evaluating the efficacy of several bacterins to immunize underyearling and post-yearling Atlantic salmon against BKD. The bacterins contained Renibacterium salmoninarum cells killed by heating, formalin inactivation, or both. Bacteria were administered by intraperitoneal injection (with and without adjuvant), or by hyperosmotic infiltration. Because the experimental fish were held after vaccination in a facility with an annual occurrence of $\mathrm{BKD}$, the investigators were able to measure the antibody response to each bacterin and assess the ability of each to confer resistance to natural challenge. The highest agglutinating antibody titers were measured in both the underyearling and post-yearling Atlantic salmon that received killed $R$. salmoninarum cells in Freund's complete adjuvant. The humoral response appeared to depend on the method of immunization, because either elimination of the adjuvant or substitution of hyperosmotic immersion for injection significantly reduced antibody titers. The length of the immune response in the underyearlings was 69 to $88 \mathrm{wk}$ - insufficient to confer protection to the time of smoltification. In the fish immunized as postyearlings, high antibody titers were measured for about $1 \mathrm{yr}$. The authors reported a reduced prevalence of $\mathrm{BKD}$ lesions in the vaccinates compared to controls when both were observed as smolts 1 yr after vaccination. Unfortunately, there appeared to be no difference in the $R$. salmoninarum infection rates when tissues of asymptomatic fish from both groups were examined by the indirect FAT.

McCarthy et al. (1984) reported on vaccination trials with several preparations of formalin-inactivated cells of Renibacterium salmoninarum. Four bacterins, including unaltered bacteria from culture, a doublestrength concentrate of the same bacteria, and $\mathrm{pH}$ lysed suspensions of both preparations, were tested for their ability to protect rainbow trout against an injected challenge with live $R$. salmoninarum. At least $34 \mathrm{~d}$ before challenge, the bacterins were administered without adjuvant to the fish by either intraperitoneal injection, direct immersion, or hyperosmotic infiltration. In agreement with the results of Paterson et al. (1981a), McCarthy et al. (1984) showed an absence of measurable protection in fish vaccinated by hyperosmotic infiltration; in addition, McCarthy et al. found a lack of protection in fish exposed to bacterin by direct immersion. Their results suggested that fish vaccinated with bacterins by intraperitoneal injection were protected against infection, and that the pH-lysed bacterins gave the best apparent protection. These results cannot be compared with those of Paterson et al. (1981a) who detected little or no specific antibody response in fish injected with bacterin without adjuvant, and who apparently did not test fish vaccinated in this manner for protection. Furthermore, McCarthy et al. (1984) did not measure antibody levels; and because the Gram stain was used to measure the prevalence of infection, one must be cautious in interpreting their results; Gram staining lacks the sensitivity of the commonly used FAT (Bullock et al. 1980, Paterson et al. 1981b).

Although the various reports suggest that it might be possible to develop a protective anti-BKD vaccine, they also illustrate the complexity of the problem. Although salmonids are able to produce specific antibody against experimental Renibacterium salmoninarum bacterins, it has not been clearly shown that the presence of such antibodies confers protection. Weber \& Zwicker (1979) and Bruno (1987) also demonstrated elevated antibody titers in the serum of farmed and wild Atlantic salmon and farmed rainbow trout naturally exposed to $R$. salmoninarum; however, Bruno could find no correlation between the agglutinating antibody titers in the sera of farmed Atlantic salmon and their BKD infection levels, although he noted that the titers of sera from noninfected, subclinically infected, and clinically infected rainbow trout generally correlated with the level of BKD infection.

There is evidence that the nature of the Renibacterium salmoninarum antigen selected for a BKD vaccine might influence its ability to confer protective immunity. Turaga et al. (1987) reported that the production of antibodies in vitro by artificially stimulated 
normal coho salmon lymphocytes was suppressed when a soluble antigen fraction derived from a culture of $R$. salmoninarum was present in the medium at concentrations of $10 \mu \mathrm{g} \mathrm{ml}^{-1}$ and $100 \mu \mathrm{g} \mathrm{ml}^{-1}$. Suppression of antibody production was similar in cultures of lymphocytes from BKD-infected coho salmon, and could be correlated with soluble antigen levels between 3 and 80 $\mu \mathrm{g} \mathrm{ml} \mathrm{m}^{-1}$ in the blood of the infected fish.

It is reasonable to speculate that the incorporation of a marginally effective bacterin for $\mathrm{BKD}$ into one that includes antigens from other bacterial pathogens known to induce protective immunity in fish might provide an indirect immunologic boost sufficient to protect the fish from infection against each of the pathogens, including Renibarterimm salmoninarum. Salmon and trout have been successfully immunized against several bacterial pathogens, and some commercially produced bacterins are now available isee e. g. Gould et al. 1979, Amend et al. 1983, Adams et al. 1988, Ellis 1988). One such pathogen, Vibrio anguillarum, has in fact been shown to possess a substance that stimulates mitogenesis and polyclonal activation of salmonid lymphocytes (Yui \& Kaattari 1987). These findings prompted Kaattari et al. (1987) to test the feasibility of improving the protective immune response to $R$. salmoninarum by combining antigens from this organism with antigens from $V$. anguillarum. A soluble antigen fraction from an $R$. salmoninarum culture was conjugated to killed $V$. anguillarum cells by either glutaraldehyde, cyanuric chloride, ethyl carbodimide or tannic acid. A soluble antigen extracted from $V$. anguillarum cells was conjugated to killed $R$. salmoninarum cells by glutaraldehyde. Various groups of coho salmon were vaccinated by intraperitoneal injection with these preparations (one preparation per group), or with a suspension of heat-killed $R$. salmoninarum cells; controls were injected with phosphate-buffered saline. Testing of antibody and cellular immune responses to $R$. salmoninarum $21 \mathrm{~d}$ after vaccination, and just before challenge with this bacterium, indicated a variable response to all preparations and a lack of correlation with protection. A comparison of mortality among the groups suggested that some protection may have been conferred by administering the heat-killed $R$. salmoninarum cells, the soluble antigen of $R$. salmoninarum conjugated to $V$. anguillarum cells by tannic acid, or the soluble extract of $V$. anguillarum cells conjugated to heat-killed $R$. salmoninarum cells by glutaraldehyde. However, when these 3 immunogens were retested in a similar vaccine trial, no protective effect was observed (Kaattari et al. 1988). The authors postulated that the immune response of a fish might vary with the type of vaccine and immunization schedule used, and that sometimes an inappropriate response may exacerbate the disease.
Other investigators have tested the effects of combining (without conjugation) antigens of Renibacterium salmoninarum in a bacterin with antigens of other fish pathogens. Amend \& Johnson (1984) looked for the occurrence of antigenic competition when antigens of 2 or more fish pathogens were combined in a bacterin. Interference among the antigens could result in reduced efficacy in a multivalent bacterin (Pross \& Eidinger 1974). Vibrio anguillarum, Aeromonas salmonicida, and $R$. salmoninarum were tested as monovalent and multivalent bacterins. Commercially prepared $V$. anguillarum bacterin was used in conjunction with bacterins made with pH-lysed $R$, salmoninarum cells and with $A$. salmonicida cells lysed with ethylenediamine tetraacetic acid. Bacterins were administered to coho salmon by intraperitoneal injection. Thirty days after vaccination, the fish were challenged by injection with either $V$. anguillarum or $A$. salmonicida (strains homologous to bacterin strains) but not with $R$. salmoninarum. Although the $R$. salmoninarum cross challenge was not done, results showed that no loss of protection from a $V$. anguillarum challenge occurred as a result of using a trivalent bacterin. Rather, the combination of the $A$. salmonicida and $R$. salmoninarum bacterins conferred significantly better protection against $A$. salmonicida than did the $A$. salmonicida bacterin alone. The authors suggested that the 2 bacteria might share some common antigens that potentiated protection against $A$. salmonicida. It is encouraging that no antigenic interference was found, but because an $R$. salmoninarum challenge was not done, no conclusions can be drawn about benefits of a multivalent BKD vaccine.

Some researchers believe that the species of fish also affects the success of immunization programs. Evelyn et al. (1988) conducted an extensive study in which various preparations containing cell-associated and extracellular antigens from a formalin-killed Renibacterium salmoninarum culture failed to protect sockeye salmon and coho salmon against either natural or experimental $R$. salmoninarum challenges. Vaccines were administered by intraperitoneal injection (with and without adjuvant), as well as by feeding, spraying or hyperosmotic infiltration. Regardless of the antigen preparation or the method of vaccination, there were no differences in mortality between vaccinated and unvaccinated groups of fish. They noted that preliminary experiments had shown that both sockeye salmon and coho salmon were capable of producing antibodies in response to formalin-killed $R$. salmoninarum and therefore recognized it as a foreign antigen. From these data, Evelyn et al. (1988) postulated that fishes of the genus Oncorhynchus may be intrinsically incapable of mounting a protective immune response to BKD comparable to that reported for the genus Salmo. 


\section{GENETIC MANIPULATION}

An aspect of fish culture that has been subjected to only limited study is the potential of genetic manipulation of fish stocks to increase resistance to BKD. Suzumoto et al. (1977) tested the resistance to an injected Renibacterium salmoninarum challenge of juvenile coho salmon of 3 transferrin genotypes. Transferrin is an iron-binding plasma protein implicated in resistance to various infectious diseases (Sussman 1974). Suzumoto et al. (1977) reported significant differences in mortality between two of the transferrin genotypes. The results must be interpreted with caution, however, because few fish were used for the tests, and because, for statistical analysis, the mortality data from groups injected with 2 different levels of iron and one group not injected with iron were pooled for each transferrin genotype. The results of further research by Winter et al. (1980) suggested that the importance of a given transferrin genotype in the resistance of coho salmon to BKD varied from one fish stock to another. These findings indicate that the influence of genotype on disease resistance warrants further investigation.

\section{PREVENTION OF HORIZONTAL TRANSMISSION}

Little work has been directed to the prevention of horizontal transmission. The mechanism(s) by which horizontal transmission of BKD occurs is not understood, although it is known that the causative bacterium can be spread to healthy fish from infected fish living in the water supply (Mitchum \& Sherman 1981, Bell et al. 1984). Research has shown that Renibacterium salmoninarum is shed in the feces (Bullock et al. 1980, Austin \& Rayment 1985) and that it can survive for several weeks in the environment. Austin \& Rayment (1985) infected groups of rainbow trout with $R$. salmoninarum by intraperitoneal injection, then held them in laboratory tanks. For up to $16 \mathrm{wk}$, the authors cultured weekly samples of the tank water, as well as feces and sediment from each tank on a selective medium for $R$. salmoninarum. They successfully cultured the bacterium from the fecal/sediment samples for up to $21 \mathrm{~d}$ after the last fish died; the estimated $R$. salmoninarum concentration was $8 \times 10^{3}$ cells per $\mathrm{g}$ material. Because $R$. salmoninarum was not detected in any water samples, the authors concluded that the bacterium may have an affinity for organic, particulate matter. The results of these experiments suggested that freshwater supplies contaminated with $R$. salmoninarum in feces can be a source of infection.

Horizontal transmission may also occur in seawater Evelyn (1988) demonstrated that Renibacterium salmoninarum can survive up to $12 \mathrm{~d}$ in filter-sterilized seawater (salinity $32 \%$ ). He further reported that 2 groups of juvenile sockeye salmon found to be free of $R$. salmoninarum by Gram stain and culture subsequently became infected while they were held for several months in seawater cages adjacent to cages containing BKD-infected salmon.

Several studies have addressed disinfection or sterilization of hatchery water supplies. Such procedures are considered potentially useful in at least 3 aspects of fish population management (Wedemeyer \& Nelson 1977), including: (1) elimination of pathogens from hatchery source water which otherwise would be unsuitable because of enzootic fish diseases, (2) the destruction of fish pathogens in water reuse systems to prevent the spread of disease throughout a hatchery, and (3) protection of the environment by the destruction of pathogens in hatchery effluent. Ozone disinfection and ultraviolet (UV) irradiation have been used successfully for the destruction of several fish pathogenic bacteria (see e. g. Conrad et al. 1975, Bullock \& Stuckey 1977, Wedemeyer \& Nelson 1977, Colberg \& Lingg 1978, Austin 1983, Sako \& Sorimachi 1985).

Limited research has been reported on the feasibility of destroying Renibacterium salmoninarum in contaminated water supplies by disinfection or sterilization. Austin (1983) tested ozonization for disinfecting laboratory effluent that was known to receive large numbers of $R$. salmoninarum cells. After preparing bacteriological cultures from monthly samples of treated and untreated effluent for 1 yr, he determined that residual ozone concentrations as low as $0.1 \mathrm{mg} \mathrm{l}^{-1}$ were effective for killing all the $R$. salmoninarum in the effluent, although he did not state the range of concentrations of this bacterium that were present in the effluent before disinfection. We have not found published reports of tests of UV irradiation for inactivation of $R$. salmoninarum. Flatow's (1981) review of UV irradiation in aquaculture mentioned that gram-positive marine bacteria were more easily controlled by UV irradiation than were many of the gram-negative organisms. He noted that strains of Corynebacterium sp. (the genus to which the kidney disease bacterium was once thought to belong; Ordal \& Earp 1956) were among the bacteria that were readily inactivated by UV irradiation, but he did not specifically mention the kidney disease bacterium. Clearly, more studies are necessary to determine the utility of disinfection or sterilization of water supplies for the control of BKD.

\section{PREVENTION OF VERTICAL TRANSMISSION}

\section{Egg treatment}

As circumstantial evidence accumulated indicating that $\mathrm{BKD}$ could be vertically transmitted in association 
with salmonid eggs, researchers began exploring the potential of egg surface disinfection for preventing infection. The experimental results of Ross \& Smith (1972), which showed that Renibacterium salmoninarum was killed in vitro by a 5 min exposure to iodophor (organic 'tamed' iodine) at a concentration of $25 \mathrm{mg} \mathrm{l}^{-1}$ iodine, were encouraging. However, Bullock et al. (1978) found that iodophor disinfection (exposure to $100 \mathrm{mg} \mathrm{t}^{-1}$ iodine for $15 \mathrm{~min}$ ) of eggs of spring chinook salmon and rainbow trout obtained from infected stocks did not prevent transmission of $R$. salmoninarum to the fry.

In more recent experiments, Evelyn et al. (1984) obtained eggs from a naturally infected female coho salmon whose coelomic ('ovarian') fluid rontained a large number of viable Renibacterium salmoninarum cells (about $4 \times 10^{9}$ cells $\mathrm{ml}^{-1}$ ); they exposed the unfertilized, water-hardened eggs for $15 \mathrm{~min}$ at $15^{\circ} \mathrm{C}$ to $500 \mathrm{mg} \mathrm{l}^{-1}$ iodine as iodophor - a concentration 5 times the maximum concentration recommended for egg treatment (Wood 1979, Piper et al. 1982). The tests demonstrated that the iodophor treatment eliminated most, and sometimes all, viable $R$. salmoninarum cells from the surface of the eggs, but that the intra-ovum infection rate apparently remained unchanged whether the eggs were treated or not. Histological sections of eggs showed apparent bacteria in the yolk.

To further investigate the location of the bacteria in the egg, Evelyn et al. (1986b) conducted disinfection experiments with unfertilized eggs from a ripe coho salmon whose coelomic fluid contained about $2.7 \times$ $10^{10}$ viable cells of Renibacterium salmoninarum per $\mathrm{ml}$. Some groups of eggs were water-hardened in iodophor (250 $\mathrm{mg} \mathrm{l}^{-1}$ iodine) for up to $2 \mathrm{~h}$, which presumably resulted in iodine uptake in the perivitelline space and its contact with any bacteria located there. These treatments failed to eliminate intra-ovum $R$. salmoninarum, and there was no difference in intraovum infection rates between egg groups that were water-hardened in iodophor and those that were disinfected with iodophor after they had been water-hardened. The authors concluded that none of the iodophor treatments prevented vertical transmission.

Erythromycin also has been used as an egg treatment in attempts to reduce vertical transmission of BKD, and some researchers reported success with this procedure. Klontz (1983) briefly described an experiment in which newly fertilized salmonid eggs (species not specified) were water-hardened in $2 \mathrm{mg} \mathrm{l}^{-1}$ erythromycin phosphate for $1 \mathrm{~h}$. The eggs and fry were maintained in water free of Renibacterium salmoninarum. When the fry were examined several months after hatching, $R$. salmoninarum was not detected by indirect FAT in the treated group, but was detected in the untreated controls. Jensen et al. (1981) found that treatment of coho salmon eggs with $2 \mathrm{mg} \mathrm{l}^{-1}$ of erythromycin phosphate for $1 \mathrm{~h}$ during water hardening did not affect fertilization or the initiation of water uptake into the perivitelline space. Additionally, a production group of coho salmon originating from eggs that had been water-hardened in erythromycin showed no signs of BKD up to the time of their release 18 mo after treatment (it was unclear whether untreated eggs were reared for comparison).

In contrast, other researchers observed erythromycin treatment of eggs to be without benefit for reducing vertical transmission. Groman (1983), Groman \& Klontz (1983), and Bullock \& Leek (1986) reported that erythromycin phosphate was retained for less than $24 \mathrm{~h}$, although it was readily absorbed into chinook salmon eggs at levels above the in vitro minimum inhibitory concentration for Renibacterium salmoninarum during a $1 \mathrm{~h}$ water-hardening period in $2 \mathrm{mg} \mathrm{l^{-1 }}$ erythromycin. Groman (1983) and later Evelyn et al. (1986a) concluded that erythromycin did not enter the yolk but remained in the perivitelline fluid, and diffused out after the eggs were placed in antibiotic-free running water. Evelyn et al. (1986a) determined that even relatively water-insoluble forms of erythromycin such as erythromycin stearate were leached from the eggs within $24 \mathrm{~h}$ after treatment. Groman (1983), who examined (by direct FAT) tissues of juvenile spring chinook salmon originating from erythromycin-treated and untreated egg groups, found no apparent benefit of the erythromycin waterhardening procedure recommended by Klontz (1983) for reducing the incidence of $R$. salmoninarum infection.

More recent studies have supported the findings of Groman (1983). Evelyn et al. (1986c), who infected coho salmon eggs before fertilization by bathing them for $24 \mathrm{~h}$ at $4^{\circ} \mathrm{C}$ in coelomic fluid containing $1.3 \times 10^{12}$ cells $\mathrm{ml}^{-1}$ of viable Renibacterium salmoninarum demonstrated that subsequent water-hardening of the eggs in erythromycin did not reduce the intra-ovum infection rate or prevent infection of the fry, even though the erythromycin concentration tested was 25 times higher than that recommended by Klontz (1983). Bruno \& Munro (1986) injected an adult Atlantic salmon intraperitoneally with $2.7 \times 10^{8} R$. salmoninarum cells to contaminate the eggs, and stripped eggs from the ripe fish $5 \mathrm{~d}$ later for incubation. They cultured $R$, salmoninarum from the surface or contents of unfertilized eggs that had been water-hardened in erythromycin phosphate $\left(2 \mathrm{mg} \mathrm{l}^{-1}\right.$ for $\left.30 \mathrm{~min}\right)$, penicillin $\mathrm{G}(50$ units $\mathrm{ml}^{-1}$ for $1 \mathrm{~h}$ ), or proflavin $\left(200 \mathrm{mg} \mathrm{l}^{-1}\right.$ for $30 \mathrm{~min}$ or $1 \mathrm{~h}$ ). Nevertheless, they did not detect $R$. salmoninarum in fry hatched from other egg groups, regardless of whether they had been water-hardened in antibacterial compounds $(1 \mathrm{~h}$ treatments with either erythromycin, penicillin $G$, or a combination of erythromyciri and penicillin G) or had been left untreated.

It has become apparent that the water-hardening of 
eggs in erythromycin or other antibacterial compounds is ineffective for preventing vertical transmission of Renibacterium salmoninarum because of the short contact time with the compounds at therapeutic levels, and the failure of such treatments to deliver the antibacterial agent to the egg yolk where at least some $R$. salmoninarum might occur (Evelyn et al. 1986a). To be effective for reducing or preventing vertical transmission of the bacterium, an antibacterial treatment should either reduce or eliminate the infection in the adult female, or result in the uptake and retention of therapeutic levels of the antibacterial compound within the egg yolk long enough to prevent infection of the fry.

\section{Erythromycin injection of adults}

Early experiments testing the injection of adult salmonids with erythromycin phosphate (summarized by Groman \& Klontz 1983) suggested that injections may not only reduce BKD-associated prespawning mortality, but may also help to reduce vertical transmission of the causative bacterium. One published test conducted at a production hatchery for cutthroat trout showed encouraging results (Petersen 1982). The adult fish were injected repeatedly at about monthly intervals with erythromycin phosphate at $11 \mathrm{mg}$ per $\mathrm{kg}$ body weight. Their eggs were water-hardened in $3 \mathrm{mg} \mathrm{l}^{-1}$ erythromycin (contact time unspecified). No Renibacterium salmoninarum was detected in the progeny examined by FAT or Gram stain during a 4 yr monitoring period. Unfortunately, no untreated groups of fish could be maintained at the hatchery for comparison.

Groman (1983) showed that a single injection of erythromycin phosphate at $11 \mathrm{mg}$ per $\mathrm{kg}$ body weight, administered to adult spring chinook salmon at the beginning of the prespawning holding period, resulted in erythromycin accumulation in the yolk of developing eggs; therapeutic levels of the antibiotic were measured in the eggs at the time of spawning. However, he found little or no erythromycin activity remaining $24 \mathrm{~h}$ after these eggs were water-hardened, and suggested that multiple erythromycin injections of prespawning adults might be required for retention of therapeutic levels in the eggs for a longer period. Bullock \& Leek (1986) also examined eggs and fry that were the progeny of chinook salmon that had been injected once with erythromycin phosphate at $11 \mathrm{mg}$ per $\mathrm{kg}$ body weight before spawning. In contrast to Groman (1983), they detected therapeutic levels of erythromycin in eggs tested as long as $60 \mathrm{~d}$ postfertilization, and in the yolk sacs of fry tested $70 \mathrm{~d}$ postfertilization - as well as in eggs tested immediately after a $1 \mathrm{~h}$ water-hardening period. Evelyn et al. (1986a) also found therapeutic levels of erythromycin persisting up to $77 \mathrm{~d}$ postfertiliza- tion (the longest period tested) in eggs from coho salmon brood fish that had received one or more erythromycin phosphate injections (20 mg of erythromycin base per $\mathrm{kg}$ body weight at each injection before spawning. These authors determined that the timing of erythromycin injections was important; fish that received a single injection $30 \mathrm{~d}$ before spawning (or their last injection 34 to $56 \mathrm{~d}$ before spawning) produced eggs containing therapeutic levels of erythromycin at spawning, whereas fish that received only one injection 70 or $90 \mathrm{~d}$ before spawning produced eggs containing no erythromycin or only trace amounts. The authors speculated that the absence of erythromycin in eggs from fish injected 70 and $90 \mathrm{~d}$ before spawning might have resulted from an increased opportunity for clearance of the antibiotic from the eggs, or a lack of active uptake of the antibiotic by the eggs at that stage of development. Unfortunately, the elapsed time between erythromycin injection and spawning was not reported for the experiments performed by Groman (1983) or Bullock \& Leek (1986) to allow comparison with the findings of Evelyn et al. (1986a).

There is preliminary evidence that erythromycin injections of adult fish can prevent the infection of eggs with Renibacterium salmoninarum. Evelyn et al. (1986a) briefly mentioned an experiment in which they showed that antibiotic-containing eggs from erythromycin-injected adult salmonids (species unspecified) could not be infected with $R$. salmoninarum by a procedure that had been shown to be successful for infecting antibiotic-free eggs (Evelyn et al. 1986c). In summary, erythromycin injection of adult salmonids before spawning, if carefully timed, shows promise for preventing vertical transmission of $R$. salmoninarum. The injections may result in a reduced severity of infection in the adult fish (Petersen 1982, Groman \& Klontz 1983, Sakai et al. 1986), and may also result in the persistence of therapeutic levels of the antibiotic in the egg yolk for extended periods - which may be necessary to eliminate intra-ovum infections with this slow-growing bacterium (Bullock \& Leek 1986, Evelyn et al. 1986a).

Although erythromycin injection of adult salmonids may prove useful for preventing the transmission of BKD to the progeny, Evelyn et al. (1986a) cautioned that the large-scale use of the antibiotic for injection of fish infected with high numbers of Renibacterium salmoninarum may increase the risk of selecting for erythromycin-resistant bacteria. The antibiotic injection regimen now employed also requires access to the adult fish at a specific period prior to spawning.

\section{Brood stock culling or segregation}

Certain procedures that do not involve the use of antibiotics have been suggested for reducing the verti- 
cal transmission of Renibacterium salmoninarum. The procedure of this type that has received the most attention is known as brood stock culling or brood stock segregation, and has been tested in attempts to control infectious hematopoietic necrosis virus in salmonids (Mulcahy 1983). This method involves the destruction of gametes from those brood fish that are most likely to transmit the disease to their progeny. The appropriate tissues or body fluids from each brood fish are tested for the presence of the pathogen. Until the results of adult testing are complete, gametes are held separately under refrigeration (for delayed fertilization), or fertilized eggs from each mating pair are maintained in separate incubators with separate water supplies. The gametes (or fertilized eggs) from fish identified as disease carriers are then destroyed, and the remaining eggs are fertilized (if not already done) and pooled for normal hatchery rearing. If a fish population is too small or the infection prevalence is too high to permit the elimination of any gametes, the progeny from infected fish may be grouped for rearing according to the infection levels in the parents. This segregation procedure is intended to minimize the risk of horizontal transmission of the pathogen from fish in the highinfection-level groups to those in the low-infectionlevel or specific-pathogen-free groups.

The success of brood stock culling or segregation for interrupting vertical transmission of a disease depends on the careful selection of the appropriate fish to retain for the spawning population. Investigators are now just beginning to understand some of the factors critical to the passage of Renibacterium salmoninarum from parents to progeny. Klontz (1983) expressed the view that the male was unimportant in the vertical transmission of BKD. In recent experiments, Evelyn et al. (1986c) provided supporting evidence that brood stock culling programs for control should concentrate on adult females. They postulated that $R$. salmoninarum cells might be carried on sperm into the egg micropyle during fertilization. To test this hypothesis, coho salmon eggs were inseminated while immersed in coelomic fluid containing viable $R$. salmoninarum at a concentration of $1.3 \times 10^{12}$ cells $\mathrm{ml}^{-1}$. The researchers were unable to achieve increased rates of intra-ovum infection in comparison with unfertilized eggs. In another experiment, milt from steelhead Salmo gairdneri was contaminated by adding viable cells of $R$. salmoninarum to a final concentration of $1.1 \times 10^{20}$ $\mathrm{ml}^{-1}$. Sixteen hours later, the milt was used to fertilize eggs from females free of $R$. salmoninarum. The authors did not detect infection of eggs in 2 trials involving 138 and 143 eggs fertilized with the contaminated milt. In contrast, they detected a low rate of infection in steelhead eggs immersed in coelomic fluid contaminated with $1.1 \times 10^{10}$ viable $R$. salmoninarum cells $\mathrm{ml}^{-1}$. They detected $R$. salmoninarum in 1 of 143 eggs that had been immersed in the contaminated coelomic fluid but not fertilized, and in 2 of 102 eggs fertilized with uncontaminated milt while still in the contaminated coelomic fluid.

It appears that not all infected females have the same likelihood of transmitting the infection to their progeny; the probability of vertical transmission may depend on the location of the bacteria in the fish. Evelyn et al. (1984), in an early vertical transmission study with naturally infected coho salmon, suggested that coelomic fluid was an important vehicle for the transmission of Renibacterium salmoninarum to mature eggs. They examined eggs from 5 adult fish with severe $B K D ; 4$ of the fish had cloudy coelomic fluid heavily laden with $R$. salmoninarum, whereas the other fish had clear coelomic fluid seemingly free of the bacterium. The testing of egg contents showed the presence of $R$. salmoninarum only in eggs from the females with the bacterium in the coelomic fluid. Later experiments (some discussed above) showed that coho salmon and steelhead eggs could be infected by incubating them in coelomic fluid heavily contaminated with $R$. salmoninarum for $24 \mathrm{~h}$ at $4{ }^{\circ} \mathrm{C}$ before fertilization (Evelyn et al. 1986a, c). They concluded that eggs normally acquire $R$. salmoninarum infections from the coelomic fluid after the eggs mature and are released into the body cavity. Other research results suggest that some eggs may become infected as oogonia or oocytes. Bruno \& Munro (1986) reported that intraperitoneal injection of $20 \mathrm{~g}$ rainbow trout with $2.7 \times 10^{7}$ cells of $R$. salmoninarum per fish resulted in systemic disease in $75 \%$ of the injected fish. Histological examination revealed apparent infection of some oogonia. Evelyn et al. (1986a) speculated that the vertical transmission of $R$. salmoninarum by the infection of immature eggs might be rare in nature because it had not been previously reported, and the challenge level used by Bruno \& Munro (1986) to produce infections of oogonia was so severe that few of the fish may have survived long enough to produce viable eggs. Further evaluation of ovarian infections in maturing female salmonids is needed. However, Lee \& Gordon (1987) recently detected (by indirect FAT) $R$. salmoninarum in the contents of eggs from spawning fish in which the bacterium was detected in the kidneys but not in the coelomic fluid, and suggested that the eggs may have become infected before exposure to coelomic fluid

There appears to be a correlation between the number of Renibacterium salmoninarum cells in the coelomic fluid of adult salmonids and the likelihood of vertical transmission. Evelyn et al. (1986c) produced infections in coho salmon and steelhead eggs by exposing them to $R$. salmoninarum concentrations of $1.3 \times$ $10^{12}$ and $1.4 \times 10^{9}$ cells $\mathrm{ml}^{-1}$, respectively, in coelomic 
fluid for $24 \mathrm{~h}$ before fertilization. Infections were not detected in coho salmon and steelhead eggs exposed by the same procedure to $1.3 \times 10^{6}$ and $1.4 \times 10^{3}$ cells $\mathrm{ml}^{-1}$, respectively. Infection rates were low $(\leq 5.4 \%$ for coho salmon and $\leq 6.7 \%$ for steelhead), even at the higher exposure dosages. The authors concluded that if infections did occur at the lower exposure dosages, they were uncommon enough to require the examination of more eggs for their detection.

To date, no large-scale attempts at brood stock culling or segregation for BKD control have been reported in the literature. It has been recommended by some that fish with cloudy coelomic fluid suggestive of Renibacterium salmoninarum infection (Evelyn et al. 1984), or those with clinical BKD, should not be used for spawning at production hatcheries. However, Pascho et al. (1987) recently reported the detection of $R$. salmoninarum in excess of $1 \times 10^{6}$ cells $\mathrm{ml}^{-1}$ in the coelomic fluid of adult coho salmon showing no clinical signs of BKD - indicating a need for sensitive screening techniques instead of gross observation. Although culture has proven useful for isolating $R$. salmoninarum from infected adults and eggs, the several weeks required for $R$. salmoninarum to produce visible growth (Fryer \& Sanders 1981) make culture impractical for hatchery-scale screening programs. Two new rapid detection techniques should provide a means for examining larger numbers of brood fish for $R$. salmoninarum in a shorter period of time than is possible by culture. The enzyme-linked immunosorbent assay of Pascho \& Mulcahy (1987) detects soluble antigens of $R$. salmoninarum in tissues and body fluids, and the filtration-fluorescent antibody technique of Elliott \& Barila (1987) detects whole bacteria in coelomic fluid samples after the bacteria have been concentrated on a membrane filter. The tests can be completed within a few hours. Both techniques have proved sensitive for detection and quantification of $R$. salmoninarum infections in populations of adult salmonid brood fish (Elliott $\&$ Barila 1987, Pascho et al. 1987), and are now being used in research to help define variables that are important for reducing the vertical transmission of BKD.

\section{SUMMARY AND CONCLUSIONS}

It has been difficult to study BKD, both in the field and in the laboratory, largely because of the chronic course of the disease and the fastidiousness and slow growth of the causative bacterium in culture. As a consequence of problems in detecting the infection and accurately monitoring its development, progress in finding effective treatments or preventive measures has lagged in comparison to the advances made in the control of certain other bacterial fish pathogens.
Research on vaccination or diet modification often has yielded disappointing or confusing results, whereas other potentially fruitful areas, such as changes in management practices or genetic manipulation of stocks to increase disease resistance, have received little attention. Nevertheless, recent developments in some areas of BKD control - particularly chemotherapy and the reduction of vertical transmission - have been encouraging.

The possibility of preventing BKD by the vaccination of fish has been explored by several researchers since the early 1970's. Most of the vaccination attempts have been, at best, only marginally successful. Experimental results have suggested that factors such as the bacterin delivery method, the antigen or antigens selected for vaccination, and the fish species vaccinated, all may influence the efficacy of a bacterin. The preparation of efficacious bacterins has been impeded by a lack of knowledge about the pathogenesis of BKD and the specific and nonspecific defense mechanisms in fish that are important in the defense against Renibacterium salmoninarum.

One aspect of fish husbandry that has been a target of research for over 2 decades is the effect of diet modification on the occurrence of BKD in hatchery stocks. There seems little doubt that diet formulation may affect the prevalence and severity of $\mathrm{BKD}$, but the complex relations among the various diet components and their roles in the disease process have yet to be elucidated. In recent years interest has been renewed in the hypothesis that fish fed dry diets are more likely than those fed moist diets to become affected by BKD. Since a report by Wood (1979) that coho salmon in 4 BKD-positive hatchery populations fed a dry ration showed a higher prevalence of BKD than fish fed Oregon Moist Pellets, there has been much anecdotal evidence supporting this hypothesis. A confounding problem in investigations of the hypothesis is that the commercial diets have many formulation differences other than moisture content.

Despite recommendations by Klontz (1983) and others that changes in hatchery management practices may be useful for preventing or controlling outbreaks of $\mathrm{BKD}$, little has been published on the relation between the prevalence and severity of BKD and such factors as hatchery sanitation, raceway loading densities, water flow rates, dissolved oxygen levels, fish handling procedures, or raceway design. Many hatcheries are supplied with water from rivers, lakes or impoundments that harbor Renibacterium salmoninarum infected fish. A constant extrinsic source of infection may defeat or complicate control. Success has been reported in the elimination of certain fish pathogens from water supplies by disinfection or sterilization, but the possibility of using such procedures for the 
destruction of $R$. salmoninarum has been given little attention

Many chemotherapeutic agents have been screened for efficacy against Renibacterium salmoninarum and several have been found to be useful for reducing BKDrelated mortality of juvenile salmonids during hatchery rearing, or mortality of adults during the prespawning holding period. Erythromycin has generated the most interest. More testing of orally administered erythromycin or other chemotherapeutants is needed to determine the optimum dosages, duration of treatments, and treatment intervals, for maximum clearance of the pathogen from the host, as well as maximum mortality reduction. The effectiveness of BKD-control chemotherapy of juvenile anadromous salmonids for increasing ocean survival and adult returns has not been adequately evaluated. Evenson (1982) reported better adult returns (in comparison to untreated controls) in groups of spring chinook salmon that had been given two $21 \mathrm{~d}$ treatments of erythromycin $(0.1 \mathrm{~g}$ per $\mathrm{kg}$ body weight) in feed as juveniles, but the return data were incomplete at the time of the report.

Some of the more exciting research in recent years has increased our understanding of the mechanism of vertical transmission of $\mathrm{BKD}$ and has resulted in the identification of possible methods for reducing its occurrence. Experimental evidence suggests that the adult male salmonid contributes little to the vertical transmission of Renibacterium salmoninarum. It is now apparent that at least some of the $R$. salmoninarum transmitted with salmonid eggs may be in the yolk and therefore not killed by disinfection. However, the injection of adults with erythromycin for the reduction of prespawning mortality has been found to have an added benefit, in that therapeutic levels of the antibiotic are deposited in the egg yolk and may be retained for 2 mo or more after fertilization. More research is needed to optimize adult injection regimens for the accumulation and retention of the antibiotic in the eggs. Controlled studies in hatcheries are also necessary to assess the value of the procedure for preventing vertical transmission. A recent study suggested that a single erythromycin injection of adult chinook salmon 1 to 2 mo before spawning reduced, but did not eliminate, $R$. salmoninarum infections in the fish or in their eggs (Lee \& Gordon 1987).

Another potentially useful technique is brood stock culling or segregation. Preliminary research results implicate females with high levels of Renibacterium salmoninarum in their coelomic fluid as those most likely to transmit the pathogen, and even in these cases the rate of transmission may be low. It is presumed that from a small nucleus of infected eggs and fry, the disease can be spread horizontally to other fry. There is still a need to determine if there is a threshold level of infection in adult female salmonids below which there is little risk of vertical transmission. Eliminating eggs from adults infected with low numbers of $R$. salmoninarum may be unnecessary, and may eliminate valuable genetic diversity. Both laboratory egg infection studies and hatchery brood stock segregation experiments involving large numbers of mating pairs may be needed to answer this question.

The recent development of more sensitive and quantitative techniques for BKD detection will aid in the evaluation of brood stock segregation studies and other BKD control programs. In the early days of BKD research, investigators had to rely on crude measures of disease prevalence and severity - mortality, the presence of characteristic clinical signs, or results from Gram stained tissues - to determine the effectiveness of a potential control method. Improved techniques for culturing Renibacterium salmoninarum (Evelyn 1977, Austin et al. 1983, Daly \& Stevenson 1985) have proved useful for some applications, but the slow growth of the organism has made culture impractical for applications requiring rapid diagnosis.

The advent of rapid immunological tests for BKD diagnosis was heralded by the development of the immunodiffusion test (Chen et al. 1974) and the fluorescent antibody technique (Bullock \& Stuckey 1975, Bullock et al. 1980). The immunodiffusion test did not receive wide acceptance because of its relative insensitivity (Fryer \& Sanders 1981, Kimura \& Yoshimizu 1981a, b, Cipriano et al. 1985, Pascho et al. 1987. Sakai et al. 1987). The fluorescent antibody technique could be used for examining large numbers of fish and was more sensitive than the Gram stain (the fluorescent antibody technique detected Renibacterium salmoninarum concentrations as low as $10^{4}$ cells per $\mathrm{g}$ kidney tissue compared with $10^{6}$ to $10^{9}$ cells for the Gram stain; Bullock et al. 1980, Sakai et al. 1987), but was still labor-intensive. Further refinements to the fluorescent antibody technique permitted the detection and quantification of small numbers of bacteria $1<10^{2}$ cells $\mathrm{ml}^{-1}$ ) in the coelomic fluid of adult salmonids (Elliott \& Barila 1987). Another quickly performed qualitative test, the staphylococcal coagglutination technique of Kimura \& Yoshimizu (1981a, b), was found to have sensitivity equal to that of the fluorescent antibody technique (Sakai et al. 1987), and was useful for field diagnosis of BKD. However, the sensitivity of the rapid, qualitative counterimmunoelectrophoresis test has been shown to be variable (Cipriano et al. 1985 , Pascho et al. 1987).

Finally, several researchers have developed rapid enzyme immunoassays intended for testing large numbers of samples with maximum efficiency. The modified peroxidase-antiperoxidase procedure reported by Sakai et al. (1987) is a qualitative test, whereas the 
enzyme-linked immunosorbent assay (Pascho \& Mulcahy 1987, Turaga et al. 1987) is quantitative. Both are more sensitive than the fluorescent antibody technique for the detection of subclinical infections of Renibacterium salmoninarum in tissues and body fluids for which direct comparisons have been made (Pascho et al. 1987, Sakai et al. 1987). The enzyme-linked immunosorbent assay is being used to determine the prevalence of $B K D$, to quantify the distribution of $R$. salmoninarum infection in salmonid populations (Pascho et al. 1987), and to provide a relatively precise measure of the impact of potential control strategies on these variables. It is anticipated that the use of this new diagnostic technique and others will help to expand knowledge of the disease process and facilitate progress in the control of BKD.

\section{LITERATURE CITED}

Adams, A., Auchinachie, N., Bundy, A., Tatner, M. F., Horne, M. T (1988). The potency of adjuvanted injected vaccines in rainbow trout (Salmo gairdneri Richardson) and bath vaccines in Atlantic salmon (Salmo salar L.) against furunculosis. Aquaculture 69: 15-26

Allison, L. N. (1958). Multiple sulfa therapy of kidney disease among brook trout. Prog. Fish-Cult. 20: 66-68

Amend, D. F., Fender, D. C. (1976). Uptake of bovine serum albumin by rainbow trout from hyperosmotic solutions: a model for vaccinating fish. Science 192: 793-795

Amend, D. F., Johnson, K. A. (1984). Evidence for lack of antigenic competition among various combinations of Vibrio anquillarum, Yersinia ruckeri, Aeromonas salmonicida and Renibacterium salmoninarum bacterins when administered to salmonid fishes. J. Fish Dis. 7: 293-299

Amend, D. F., Johnson, K. A., Croy, T R., McCarthy, D. H. (1983). Some factors affecting the potency of Yersinia ruckeri bacterins. J. Fish Dis. 6: 337-344

Austin, B. (1983). Effectiveness of ozone for the disinfection of laboratory effluent. FEMS Microbiol. Lett. 19: 211-214

Austin, B. (1985). Evaluation of antimicrobial compounds for the control of bacterial kidney disease in rainbow trout, Salmo gairdneri Richardson. J. Fish Dis. 8: 209-220

Austin, B., Embley, T M., Goodfellow, M. (1983). Selective isolation of Renibacterium salmoninarum. FEMS Microbiol. Lett. 17: 111-114

Austin, B., Rayment, J. N. (1985). Epizootiology of Renibacterium salmoninarum, the causal agent of bacterial kidney disease in salmonid fish. J. Fish Dis. 8: 505-509

Austin, B., Rodgers, C. J. (1980). Diversity among strains causing bacterial kidney disease in salmonid fish. Curr. Microbiol. 3: 231-235

Banner, C. R., Long, J. J., Fryer, J. L., Rohovec, J. S. (1986). Occurrence of salmonid fish infected with Renibacterium salmoninarum in the Pacific Ocean. J. Fish Dis. 9: 273-275

Banner, C. R., Rohovec, J. S., Fryer, J. L. (1983). Renibacterium salmoninarum as a cause of mortality among chinook salmon in salt water. J. World Maricult. Soc. 14: 236-239

Belding, D. L, Merrili, B. (1935). A preliminary report upon a hatchery disease of the Salmonidae. Trans. Am. Fish. Soc. 65: $76-84$

Bell, G. R., Higgs, D. A., Traxler, G. S. (1984). The effect of dietary ascorbate, zinc, and manganese on the development of experimentally induced bacterial kidney disease in sockeye salmon (Oncorhynchus nerka). Aquaculture 36 : 293-311

Bell, G. R., Traxler, G. S., Dworschak, C. (1988). Development in vitro and pathogenicity of an erythromycin-resistant strain of Renibacterium salmoninarum, the causative agent of bacterial kidney disease in salmonids. Dis. aquat. Org. 4 : 19-25

Bowser, P. R., Landy, R. B., Wooster, G. A. (1988). Efficacy of elevated dietary fluoride for the control of Renibacterium salmoninarum infection in rainbow trout Salmo gairdneri. J. World Aquacult. Soc. 19: 1-7

Brittain, D. C. (1987). Update on antibiotics I. Erythromycin. Med. Clin. North Am. 71: 1147-1154

Bruno, D. W. (1986). Histopathology of bacterial kidney disease in laboratory infected rainbow trout, Salmo gaironeri Richardson, and Atlantic salmon, Salmo salar L., with reference to naturally infected fish. J. Fish Dis. 9: 523-537

Bruno, D. W. (1987). Serum agglutinating titres against Renibacterium salmoninarum the causative agent of bacterial kidney disease, in rainbow trout, Salmo gairdneri Richardson, and Atlantic salmon, Salmo salar L. J. Fish Biol. 30: 327-334

Bruno, D. W., Munro, A. L. S. (1986). Observations on Renibacterium salmoninarum and the salmonid egg. Dis. aquat. Org. 1: $83-87$

Bullock, G. L. (1980). Bacterial kidney disease of salmonid fishes caused by Renibacterium salmoninarum. U. S. Fish. Wildl. Serv. Fish Dis. Leaflet 60

Bullock, G. L., Griffin, B. R., Stuckey, H. M. (1980). Detection of Corynebacterium salmoninus by direct fluorescent antibody test. Can. J. Fish. Aquat. Sci. 37: 719-721

Bullock, G. L., Leek, S. L. (1986). Use of erythromycin in reducing vertical transmission of bacterial kidney disease. Vet. Hum. Toxicol. 28 (Suppl. 1): 18-20

Bullock, G. L., Stuckey, H. M. (1975). Fluorescent antibody identification and detection of the Corynebacterium causing kidney disease of salmonids. J. Fish. Res. Bd Can. 32: 2224-2227

Bullock, G. L., Stuckey, H. M. (1977). Ultraviolet treatment of water for destruction of five gram-negative bacteria pathogenic to fish. J. Fish. Res. Bd Can. 34: 1244-1249

Bullock, G. L., Stuckey, H. M., Mulcahy, D. (1978). Corynebacterial kidney disease: egg transmission following iodophore disinfection. Fish. Health News 7: 51-52

Chen, P. K., Bullock, G. L., Stuckey, H. M., Bullock, A. C. (1974). Serological diagnosis of corynebacterial kidney disease of salmonids. J. Fish. Res. Bd Can. 31: 1939-1940

Cipriano, R. C., Starliper, C. E., Schachte, J. H. (1985). Comparative sensitivites of diagnostic procedures used to detect bacterial kidney disease in salmonid fishes. J. Wildl. Dis. 21: 144-148

Colberg, P. J., Lingg, A. J. (1978). Effect of ozonation on microbial fish pathogens, ammonia, nitrate, nitrite, and $\mathrm{BOD}$ in simulated reuse hatchery water. J. Fish. Res. Bd Can. 35: 1290-1296

Conrad, J. F., Holt, R. A., Kreps, T. D. (1975). Ozone disinfection of flowing water. Prog. Fish-Cult. 37: 134-136

Daly, J. G., Stevenson, R. M. W. (1985). Charcoal agar, a new growth medium for the fish disease bacterium Renibac. terium salmoninarum. Appl. environ. Microbiol. 50: 868-871

DeCew, M. G. (1972). Antibiotic toxicity, efficacy, and teratogenicity in adult spring chinook salmon (Oncorhynchus tshawytscha). J. Fish. Res. Bd Can. 29: 1513-1517

Earp, B. J., Ellis, C. H., Ordal, E. J. (1953). Kidney disease in young salmon. Washington State Department of Fisheries, Olympia, Spec. Rep. Ser. 1 
Elliott, D. G., Barila, T Y (1987). Membrane filtration-fluorescent antibody staining procedure for detecting and quantitying Renibacterium salmoninarum in coelomic fluid of chinook salmon (Oncorhynchus tshawytscha). Can. J. Fish. Aquat. Sci. 44: 206-210

Ellis, A. E. (1988). Current aspects of fish vaccination. Dis. aquat. Org. 4. 159-164

Evelyn, T P. T (1971). The agglutinin response in sockeye salmon vaccinated intraperitoneally with a heat-killed preparation of the bacterium responsible for salmonid kidney disease. J. Wildl. Dis. 7: 328-335

Evelyn, T. P. T. (1977). An improved growth medium for the kidney disease bacterium and some notes on using the medium. Bull. off. Int. Epizoot. 87: 511-513

Evelyn, T. P. T (1988). Bacterial kidney disease in British Columbia, Canada: comments on its epizootiology and methods for its control on fish farms. In: AQUA NOR 87 Trondheim International Conference, Norske Fiskeoppdretteres Forening - Fiskeoppdretternes Salgslag A/L, Trondheim, Norway, p. 51-57

Evelyn, T P. T., Ketcheson, J. E., Prosperi-Porta, L. (1984). Further evidence for the presence of Renibacterium salmoninarum in salmonid eggs and for the failure of povidone-iodine to reduce the intra-ovum infection rate in water-hardened eggs. J. Fish Dis. 7: 173-182

Evelyn, T. P. T., Ketcheson, J. E., Prosperi-Porta, L. (1986a) Use of erythromycin as a means of preventing vertical transmission of Renibacterium salmoninarum. Dis. aquat. Org. 2: 7-11

Evelyn, T P. T., Ketcheson, J. E., Prosperi-Porta, L. (1988). Trials with anti-bacterial kidney disease vaccines in two species of Pacific salmon. In: Conference Handbook, International Fish Health Conference, Vancouver, B. C. Canada, 1988. Fish Health Section, American Fisheries Society, Washington, D. C., p. 38

Evelyn, T. P. T., Prosperi-Porta, L., Ketcheson, J. E. (1986b). Persistence of the kidney-disease bacterium, Renibacterium salmoninarum, in coho salmon, Oncorhynchus kisutch (Walbaum), eggs treated during and after waterhardening with povidone-iodine. J. Fish Dis. 9: 461-464

Evelyn, T. P. T., Prosperi-Porta, L., Ketcheson, J. E. (1986c). Experimental intra-ovum infection of salmonid eggs with Renibacterium salmoninarum and vertical transmission of the pathogen with such eggs despite their treatment with erythromycin. Dis. aquat. Org. 1: 197-202

Evenson, M. D. (1982). Evaluation of erythromycin for control of bacterial kidney disease in spring chinook salmon at Cole Rivers Hatchery. In: Proceedings of the 33rd Northwest Fish Culture Workshop, Gleneden Beach, Oregon, 1982, U.S. Dept. of Commerce, National Marine Fisheries Service, Portland, Oregon, p. 187-193

Flatow, R. E. (1981). High dosage ultraviolet water purification: an indispensible tool for recycling, fish hatcheries and heated effluent aquaculture. In: Tiews, K. (ed.) Aquaculture in heated effluents and recirculation systems, Vol. 1 , H. Heenemann, Berlin, p. 455-466

Fryer, J. L., Sanders, J. E. (1981). Bacterial kidney disease of salmonid fish. Ann. Rev. Microbiol. 35: 273-298

Getchell, R. G., Rohovec, J. S., Fryer, J. L. (1985). Comparison of Renibacterium salmoninarum isolates by antigenic analysis. Fish Pathol. 20: 149-159

Gould, R. W., Antipa, R., Amend, D. F. (1979). Immersion vaccination of sockeye salmon (Oncorhynchus nerka) with two pathogenic strains of Vibrio anguillarum. J. Fish. Res. Bd Can. 36: 222-225

Groman, D. B. (1983). Studies examining the identification, epizootiology and control of Renibacterium salmoninarum infections in chinook salmon (Oncorhynchus tshawytscha). Doctoral diss., University of Idaho, Moscow

Groman. D. B.. Klontz, G. W (1983). Chemotherapy and prophylaxis of bacterial kidney disease with erythromycin. J. World Maricult. Soc. 14: 226-235

Jensen, J. O. T., McLean, W. E., Aldridge, D. F. (1981). Effects of accessory factors on survival of newly fertilized salmonid eggs treated with an antibiotic. Aquaculture 23 : 295-307

Kaattari, S., Chen, D., Turaga, P., Wiens, G. (1988). Development of a vaccine for bacterial kidney disease. Bonneville Power Administration, Project 84-46, Annual report 1987. Portiand, Oregon

Kaattari, S., Holland, N., Turaga, P.. Weins, G. (1987). Development of a vaccine for bacterial kidney disease. Bonneville Power Administration, Project 84-46, Annual report 1986, Portland, Oregon

Kimura, T., Yoshimizu, M. (1981a). Rapid method for detection of bacterial kidney disease of salmonid (BKD) by coagglutination of antibody sensitized protein A-containing staphylococci. Bull. Jap. Soc. scient. Fish. 47: 1173-1183

Kimura, T., Yoshimizu, M. (1981b). A coagglutination test with antibody-sensitized staphylococci for rapid and simple diagnosis of bacterial kidney disease (BKD). Devel. Biol. Stand. 49: 135-148

Klontz, G. W. (1983). Bacterial kidney disease in salmonids: an overview. In: Anderson, D. P., Dorson, M., Dubourget, Ph. (eds.) Antigens of fish pathogens: development and production for vaccines and serodiagnostics. Collection Foundation Marcel Merieux, Lyon, p. 177-199

Lall, S. P., Paterson, W. D., Hines, J. A., Adams, N. J. (1985) Control of bacterial kidney disease in Atlantic salmon, Salmo salar L., by dietary modification. J. Fish Dis. 8 $113-124$

Lee, E. G.-H., Gordon, M. R. (1987). Immunofluorescence screening of Renibacterium salmoninarum in the tissues and eggs of farmed chinook salmon spawners. Aquaculture 65: 7-14

McCarthy, D. H., Croy, T R., Amend, D. F. (1984). Immunization of rainbow trout, Salmo gairdneri Richardson, against bacterial kidney disease: preliminary efficacy evaluation. J. Fish Dis. 7: 65-71

Mitchum, D. L., Sherman, L. E. (1981). Transmission of bacterial kidney disease from wild to stocked hatchery trout. Can. J. Fish. Aquat. Sci. 38: 547-551

Moffitt, C. M., Schreck, J. A. (1988). Accumulation and depletion of orally administered erythromycin thiocyanate in tissues of chinook salmon. Trans. Am. Fish. Soc. 117 $394-400$

Mulcahy, D. (1983). Control of mortality caused by infectious hematopoietic necrosis virus. In: Leong, J. C., Barila, T Y (eds.) Proceedings of a workshop on viral diseases of salmonid fishes in the Columbia River basin, October 7-8, 1982. Bonneville Power Administration, Portland, Oregon, Spec. Publ., p. 51-71

Ordal, E. J., Earp, B. J. (1956). Cultivation and transmission of the etiological agent of kidney disease in salmonid fishes. Proc. Soc exp. Biol. Med. 92: 85-88

Pascho. R. J., Elliott, D. G., Mallett, R. W., Mulcahy, D. (1987). Comparison of five techniques for the detection of Renibacterium salmoninarum in adult coho salmon. Trans. Am. Fish. Soc. 11. 882-890

Pascho, R. J., Mulcahy, D. (1987). Enzyme-linked immunosorbent assay for a soluble antigen of Renibacterium salmoninarum, the causative agent of bacterial kidney disease. Can. J. Fish. Aquat. Sci. 44: 183-191

Paterson, W. D., Desautels, D., Weber, J. M. (1981a). The 
immune response of Atlantic salmon, Salmo salar L., to the causative agent of bacterial kidney disease, Renibacterium salmoninarum. J. Fish Dis. 4: 99-111

Paterson, W D., Lall, S. P., Airdrie, D., Greer, P., Greenham, G., Poy, M. (1985). Prevention of disease in salmonids by vaccination and dietary modification. Fish Pathol. 20: $427-434$

Paterson, W D., Lall, S. P., Desautels, D. (1981b). Studies on bacterial kidney disease in Atlantic salmon /Salmon [sic] salar) in Canada. Fish Pathol. 15: 283-292

Peterson, J. E. (1982). Analysis of bacterial kidney disease (BKD) and BKD control measures with erythromycin phosphate among cutthroat trout (Salmo clarki bouveri). Salmonid $5(6): 12-15$

Piper, R. G. (1961). Toxic effects of erythromycin thiocyanate on rainbow trout. Prog. Fish-Cult. 23: 134-135

Piper, R. G., McElwain, I. B., Orme, L. E., McCraren, J. P., Fowler, L. G., Leonard, J. R. (1982). Fish hatchery management. U. S. Fish Wildl. Serv. Washington, D. C.

Pross, H. F., Eidinger, D. (1974). Antigenic competition: a review of non-specific antigen-induced suppression. Adv. Immunol. 18: 133-168

Ross, A. J., Smith, C. A. (1972). Effect of two iodophores on bacterial and fungal fish pathogens. J. Fish. Res. Bd Can. 29: $1359-1361$

Rucker, R. R., Bernier, A. F., Whipple, W. J., Burrows, R. E. (1951). Sulfadiazine for kidney disease. Prog. Fish-Cult 13: $135-137$

Rucker, R. R., Earp, B. J., Ordal, E. J. (1954). Infectious diseases of Pacific salmon. Trans. Am. Fish. Soc. 83: 297-312

Sakai, D. K., Nagata, M., Iwami, T., Kiode, N., Tamiya, Y., Ito, Y., Atoda, M. (1986). Attempt to control BKD by dietary modification and erythromycin chemotherapy in hatcheryreared masu salmon Onchorynchus masou Brevoort. Bull. Jap. Soc. scient. Fish. 52: 1141-1147

Sakai, M., Koyama, G., Atsuta, S., Kobayashi, M. (1987). Detection of Renibacterium salmoninarum by a modified peroxidase-antiperoxidase (PAP) procedure. Fish Pathol. 22: $1-5$

Sako, H., Sorimachi, M. (1985). Susceptibility of fish pathogenic viruses, bacteria and fungus to ultraviolet irradiation and the disinfectant effect of U.V.-ozone water sterilizer on the pathogens in water. Bull natn. Res. Inst. Aquacult. 8: 51-58

Schreck, J. A., Moffitt, C. M. (1987). Palatability of feed containing different concentrations of erythromycin thiocyanate to chinook salmon. Prog. Fish-Cult. 49: 241-247

Smith, I. W. (1964). The occurrence and pathology of Dee disease. Fresh Water Salmon Res. 34: 3-9

Snieszko, S. F., Griffin, P. J. (1955). Kidney disease in brook trout and its treatment. Prog. Fish-Cult. 17: 3-13
Sussman, M. (1974). Iron and infection. In: Jacobs, A., Worwood, $M$. (eds.) Iron in biochemistry and medicine. Academic Press, New York, p. 649-699

Suzumoto, B. K., Schreck, C. B., McIntyre, J. D. (1977). Relative resistances of three transferrin genotypes of coho salmon (Oncorhynchus kisutch) and their hematological responses to bacterial kidney disease. J. Fish. Res. Bd Can. 34: $1-8$

Turaga, P., Wiens, G., Kaattari, S. (1987). Bacterial kidney disease: the potential role of soluble protein antigen(s). J. Fish Biol. 31 (Suppl. A): 191-194

Warren, J. W. (1963). Toxicity tests of erythromycin thiocyanate in rainbow trout. Prog. Fish-Cult. 25: 88-92

Weber, J. M., Zwicker, B. M. (1979). Aeromonas salmonicida in Atlantic salmon (Salmo salar): Occurrence of specific agglutinins to three bacterial pathogens. J. Fish. Res. Bd Can. 36: 1102-1107

Wedemeyer, G. A., Nelson, N. C. (1977). Survival of two bacterial fish pathogens (Aeromonas salmonicida and the enteric redmouth bacterium) in ozonated, chlorinated, and untreated waters. J. Fish. Res. Bd Can. 34: 429-432

Wedemeyer, G. W., Ross, A. J. (1973). Nutritional factors in the biochemical pathology of corynebacterial kidney disease in the coho salmon (Oncorhynchus kisutch). J. Fish. Res. Bd Can. 30: 296-298

Winter, G. W. Schreck, C. B, McIntyre, J. D. (1980). Resistance of different stocks and transferrin genotypes of coho salmon, Oncorhynchus kisutch, and steelhead trout, Salmo gairdneri, to bacterial kidney disease and vibriosis. Fish. Bull. U. S. 77. 795-802

Wolf, K., Dunbar, C. E. (1959). Test of 34 therapeutic agents for control of kidney disease in trout. Trans. Am. Fish. Soc. 88: $117-134$

Wood, J. W. (1979). Diseases of Pacific salmon, their prevention and treatment, 3rd edn. Washington Department of Fisheries, Hatchery Division, Olympia, Washington

Wood, J. W., Wallis, J. (1955). Kidney disease in adult chinook salmon and its transmission by feeding to young chinook salmon. Res. Briefs, Fish. Commission of Oregon 6(2): $32-40$

Woodall, A. N., LaRoche, G. (1964). Nutrition of salmonid fishes. XI. lodide requirements of chinook salmon. J. Nutr 82: $475-482$

Young, C. L., Chapman, G. B. (1978). Ultrastructural aspects of the causative agent and renal histopathology of bacterial kidney disease in brook trout (Salvelinus fontinalis). J. Fish. Res. Bd Can. 35: 1234-1248

Yui, M. A., Kaattari, S. L. (1987). Vibrio anguillarum antigen stimulates mitogenesis and polyclonal activation of salmonid lymphocytes. Devel. Comp. Immunol. 11: $539-549$ 